\title{
Pengamatan Jangka Panjang Remaja dengan Gizi Buruk Tipe Marasmus Kwashiorkor dan Short Bowel Syndrome et causa Perforasi Yeyunum
}

\author{
Rinche Annur ${ }^{1}$, Yusri Dianne Jurnalis ${ }^{2}$, Eva Chundrayetti ${ }^{2}$, Yorva Sayoeti ${ }^{2}$
}

\begin{abstract}
Abstrak
Gizi buruk terjadi akibat gangguan gizi kronik dan menyebabkan gangguan pertumbuhan yang berpengaruh terhadap kesehatan, kecerdasan dan produktivitas saat beranjak dewasa. Kecukupan nutrisi remaja sangat penting agar selaras dengan pacu tumbuh dan merupakan investasi untuk generasi yang lebih baik. Short bowel syndrome merupakan kondisi gangguan malabsorpsi akibat reseksi usus halus ekstensif dan memerlukan nutrisi parenteral > 42 hari setelah reseksi usus. Pengamatan jangka panjang dilakukan pada remaja dengan gizi buruk tipe marasmik kwashiorkor dengan short bowel syndrome et causa perforasi yeyunum dan anemia defisiensi besi. Pasien selalu mengeluh nyeri perut bila mendapat makanan padat, muntah, diare, penurunan nafsu makan dan berat badan dengan status gizi buruk. Penelusuran etiologi didapatkan perforasi yeyunum sehingga dilakukan yeyunostomi dan prosedur Santulli. Selama rawatan pasien mengalami short bowel syndrome dan ditatalaksana dengan kombinasi nutrisi parenteral dan enteral peroral. Akhir pemantauan berat badan menjadi $37 \mathrm{~kg}$ dengan kesan gizi baik. Penatalaksanaan yang tepat pada penderita gizi buruk dengan short bowel syndrome et causa perforasi yeyunum memberikan hasil akhir yang baik.
\end{abstract}

Kata kunci: gizi buruk, short bowel syndrome, perforasi yeyunum

\begin{abstract}
Malnutrition occurs due to chronic nutritional disorder, and leads to growth disorders affecting health, intelligence and productivity. Adequacy of nutrition during adolescence is very important to keep the growth spur and an investment for a better generation. Short bowel syndrome is a malabsorption disorder due to extensive intestinal resection and requires parenteral nutrition $>42$ days after bowel resection. Long-term observation was performed in an adolescent girl with marasmic-kwashiorkor-type malnutrition with short bowel syndrome et causa yeyunum perforation and iron deficiency anemia. Patient's complained of having abdominal pain during eating solid food, accompanied by vomiting, diarrhea, decreased of appetite and body weight with malnutrition status. From the etiologic search, yeyunum perforation was obtained so the yeyunostomi and Santulli's procedure were performed. During treatment the patient had short bowel syndrome and was treated with combination of parenteral and enteral nutritions. By the end of the monitoring, body weight was $37 \mathrm{~kg}$ with good nutritional status. Proper management of malnourished patients with short bowel syndrome et causa perforation yeyunum gives a good result.
\end{abstract}

Keywords: malnutrition, short bowel syndrome, perforation yeyunum

Affiliasi penulis: 1. RSUD Dr Adnaan WD Payakumbuh, 2. Bagian Ilmu Kesehatan Anak Fakultas Kedokteran Universitas Andalas. Korespondensi: yusridianne12@gmail.com Telp: 085272099830

\section{PENDAHULUAN}

Gizi buruk merupakan salah satu penyebab tersering kesakitan dan kematian anak didunia, ${ }^{1}$ juga menyebabkan gangguan pertumbuhan yang berpengaruh terhadap kesehatan, kecerdasan dan produktivitas saat dewasa nanti. ${ }^{2}$ Masa remaja ditandai pertumbuhan yang sangat pesat, kenaikan tinggi badan sekitar $20 \%$ tinggi dewasa dan berat badan sekitar $50 \%$ berat dewasa, membutuhkan 
nutrisi optimal. ${ }^{3}$ Kecukupan nutrisi remaja sangat penting agar selaras dengan pacu tumbuh dan merupakan investasi untuk generasi yang lebih baik. Remaja putri yang mengalami malnutrisi dan anemia defisiensi besi akan meningkatkan risiko mortalitas dan morbiditas yang berhubungan dengan kehamilan dan persalinan dan kemungkinan melahirkan anak dengan berat lahir rendah. Hal ini merupakan siklus malnutrisi antar generasi yang harus diputus. ${ }^{4}$

\section{KASUS}

Seorang anak perempuan usia 11 tahun 3 bulan dirawat di Bagian IImu Kesehatan Anak RS Dr M Djamil Padang dengan keluhan perut tampak membesar sejak satu minggu sebelum masuk rumah sakit. Alloanamnesis diperoleh dari ibu kandung, dengan keluhan utama perut tampak membesar sejak satu minggu sebelum masuk rumah sakit. Sebelumnya pasien mengalami demam berulang dan nyeri perut sejak satu tahun yang lalu, hilang timbul, nyeri dirasakan sekitar pusar dan meningkat bila mendapat makanan padat. Anak juga mengalami muntah sejak satu tahun yang lalu, frekuensi 1-3 x/hari, \pm 3 sendok makan perkali, berisi sisa makanan dan minuman. Berak encer sejak 1,5 bulan yang lalu, frekuensi 3$5 x /$ hari, sekitar 3 sendok makan sampai 1/2 gelas/kali, disertai lendir, berbau busuk dan 2 hari sebelum masuk RS, berak bercampur darah, frekuensi $1 \mathrm{x}$ jumlah sekitar 5 sendok makan. Nafsu makan menurun sejak sakit, anak hanya makan 3-4 sendok makan/kali. Berat badan menurun sejak satu tahun terakhir, berat badan tertinggi $26 \mathrm{~kg}$. Perut membuncit sejak satu minggu sebelum masuk RS. Tidak ada riwayat batuk lama dan riwayat kontak dengan penderita tuberkulosis paru. Buang air kecil warna dan jumlah biasa. Pasien telah dirawat di RSUD Mukomuko selama 2 hari.

Pasien merupakan anak ke 2 dari 3 bersaudara, lahir spontan, cukup bulan, ditolong bidan, berat badan lahir 3500 gram dan panjang badan lahir lupa, langsung menangis. Riwayat imunisasi dasar lengkap, booster tidak diberikan. Riwayat pertumbuhan terganggu dan perkembangan dalam batas normal. Higiene dan sanitasi lingkungan kurang. Ayah dan ibu pasien tidak tamat SD dan bekerja sebagai petani sawit dengan kesan riwayat social ekonomi rendah.

Pemeriksaan fisik pasien tampak sakit berat, sadar, tekanan darah 100/60 mmHg, frekuensi nadi 98x/menit, frekuensi nafas $24 x /$ menit, suhu $36,9 \mathrm{C}$, berat badan $8 \mathrm{~kg}$, panjang badan $111 \mathrm{~cm}, \mathrm{BB} / \mathrm{U}=20,5$ $\%$, TB/U $=75 \%$, BB/TB = 42,1 \%, Lingkar lengan atas $13 \mathrm{~cm}$, kesan gizi buruk. Pasien tampak anemis, edema, tidak ikterik dan sianotik. Lemak subkutis tipis, crazy pavement dermatosis berupa ekskoriasi, deskuamasi disertai gambaran hipopigmentasi dan hiperpigmentasi. Kelenjar limfe tidak membesar. Rambut pirang, mudah rontok. Mata cekung, konjungtiva pucat, sklera tidak ikterik. Pupil isokor dengan reflek cahaya normal, tidak ada bercak spot dan ulkus. Telinga normal. Nafas cuping hidung tidak ada. Tonsil dan faring tidak hiperemis. Mukosa mulut basah, tidak ada oral trush. JVP 5-2 $\mathrm{cmH}_{2} \mathrm{O}$. Dada simetris, tidak ada retraksi, suara nafas vesikuler, tidak ada ronki dan wheezing. Irama jantung regular, tidak ada bising. Abdomen distensi, darm countour dan darm staefung tidak ada, tampak penonjolan umbilikus, hepar dan lien tidak teraba, bising usus normal. Ditemukan Baggy pant . Rectal touche: anus dan spingter normal, mukosa licin, ampula kosong dan feces dengan warna kecoklatan, tidak bercampur darah. Akral hangat, perfusi baik dengan otot atrofi. Reflek fisiologis normal dan reflek patologis negatif. Ditemukan pitting udema di pretibia.

Pemeriksaan laboratorium didapatkan hemoglobin 5,2 gr/dl, leukosit $17.300 / \mathrm{mm}^{3}$, hitung jenis 0/1/2/84/13/0. Laju endap darah $20 \mathrm{~mm} / \mathrm{jam} 1$, hematokrit $17 \%$, retikulosit $5,2 \%$, eritrosit 2.100.000/mm3, trombosit 461.000/mm3, MCH 24,7pg, MCV 80,9fl, MCHC 30,2\%. Indeks Mentzer 38,5. Gambaran darah tepi: eritrosit anisositosis, normokrom, hipokrom, sel target, leukosit meningkat dengan netrofilia shift to the right, trombosit meningkat.

Gula darah random $66 \mathrm{mg} / \mathrm{dl}$, natrium 125 $\mathrm{mmol} / \mathrm{l}$ dan kalium 1,5 mmol/l. Kalsium 6,2 mg/dl, dengan kondisi hipoalbumin, nilai koreksinya 8,4 $\mathrm{mg} / \mathrm{dl}$, protein total $3,5 \mathrm{~g} / \mathrm{dl}$, albumin $1,2 \mathrm{~g} / \mathrm{dl}$, globulin 2,3 g/dl. Ureum $25 \mathrm{mg} / \mathrm{dl}$ dan kreatinin 0,4 mg/dl. Kolesterol total 70 mg/dl, LDL 45 mg/dl, HDL 53 mg/dl. 
Pemeriksaan Si-TIBC dan UIBC tidak bisa dilakukan, ferritin $67,83 \mathrm{mg} / \mathrm{ml}$. Urinalisis dalam batas normal. Hasil mantoux tes: indurasi $0 \mathrm{~mm}$.

Rontgen abdomen 2 posisi didapatkan kesan ileus obstruksi parsial letak tinggi. Rontgen thorax dalam batas normal. Hasil pemeriksaan feses ditemukan leukosit 4-5/LPB, eritrosit 7-8/LPB, tes darah samar positif dan tidak ditemukan parasit. Kesan: perdarahan saluran cerna. Kultur feses tidak ditemukan pertumbuhan kuman pathogen.

Hasil expertise barium enema ditemukan gambaran colitis dan distensi usus halus susp ileus obtruksi parsial tetapi pemeriksaan tidak bisa dilanjutkan ke caecum karena distensi abdomen bertambah dan berisiko perforasi sehingga dilakukan CT scan abdomen dengan kontras yang larut dalam air dengan hasil ditemukan kecurigaan massa padat dimesenterium yang menekan usus halus dan menyebabkan ileus obstruksi parsial dan ditemukan gambaran fatty liver.

Selama rawatan, nyeri perut semakin bertambah dan dilakukan laparatomi eksplorasi emergensi dan Santulli prosedur. Saat operasi, ditemukan perforasi pada yeyunum $50 \mathrm{~cm}$ dari ligamentum treizt, dilatasi pada segmen yang mengalami perforasi dan stenosis pada proksimalnya dengan kesan stenosis yeyunum. Dilakukan reseksi pada segmen yeyunum sepanjang $50 \mathrm{~cm}$ dilanjutkan dengan anastomose end to end dengan Santulli prosedur dan yeyunostomi.

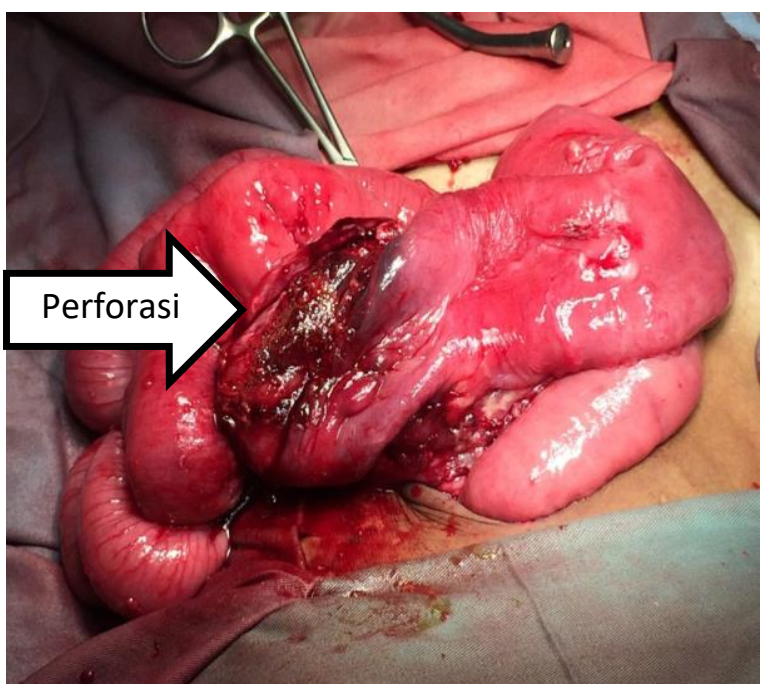

Gambar 1. Temuan intraoperatif pada pasien

\section{Diagnosis kerja}

Gizi buruk tipe marasmik kwashiorkor kondisi III, perforasi yeyunum post laparatomi eksplorasi dengan Santulli prosedur dan yeyunostomi dan anemia mikrositik hipokrom ec defisiensi besi.

\section{Penatalaksanaan}

Saat awal rawatan pasien diberikan resomal 60 cc /30 menit selama 2 jam pertama dilanjutkan 10 jam berikutnya: resomal $60 \mathrm{cc} / \mathrm{jam}$ bergantian dengan formula 75: $75 \mathrm{cc} / \mathrm{jam}$, dan dinaikkan bertahap sesuai toleransi, vitamin A $200.000 \mathrm{iu}$, asam folat $1 \times 5 \mathrm{mg}$ PO (hari pertama), dilanjutkan $1 \times 1 \mathrm{mg}$, zink $1 \times 20 \mathrm{mg}$, dicegah hipotermi dan hipoglikemia, koreksi hipokalemia dan albumin serta antibiotika berupa ampicillin 4 × $400 \mathrm{mg}$ IV dan gentamicin 2 × 30 mg IV. Setelah operasi pasien mendapatkan total parenteral nutrisi dengan IVFD D 12,5\% 12 gtt/menit makro, aminofuschin paed 5\% $220 \mathrm{cc} /$ hari, meropenem $3 \times$ $400 \mathrm{mg} \mathrm{IV}$, metronidazole 3 × $150 \mathrm{mg}$ IV. Cairan keluar dari stoma yeyunostomi sekitar $1300 \mathrm{cc}$ sampai $1800 \mathrm{cc} / \mathrm{hari}$. Urine warna jernih dan diuresis sekitar 1$2 \mathrm{cc} / \mathrm{kgBB}$. Satu minggu setelah operasi diberikan makanan cair berupa $\mathrm{F} 100$, dinaikkan bertahap menjadi makanan biasa dan parenteral nutrisi tetap diberikan berupa IVFD D $17,5 \% 1000$ cc, aminofuschin paed $5 \% 300 \mathrm{cc} /$ hari. Berat badan naik bertahap menjadi $12 \mathrm{~kg}$. Feces sudah keluar dari anus, jumlah 50-100 gram perhari, konsistensi lunak.

Setelah 2 bulan post yeyunostomi dilakukan penutupan stoma yeyunostomi dan masih diberikan total parenteral nutrisi dengan IVFD D 12,5\% 700 cc/hari, aminofuschin paed $500 \mathrm{cc} /$ hari, dengan Glucosa infussion rate 7 dan cefotaxim 2x500 mg IV. Saat bising usus membaik, pasien diberikan makanan cair bertahap mulai dari formula 75 dan dinaikkan menjadi formula 100, kemudian formula 135 dan dilanjutkan makanan lunak. Saat pulang pasien telah mendapat makanan biasa dan berat badan telah mencapai $15 \mathrm{~kg}$.

Selama pemantauan, berat badan dan tinggi badan pasien mengalami kenaikan. Pada pemantauan terakhir berat badan sudah mencapai $37 \mathrm{~kg}$ dan tinggi badan $145 \mathrm{~cm}$ dengan kesan gizi baik. Pasien 
sebelumnya mengalami anemia mikrositik hipokrom ec defisiensi besi, sekarang sudah mengalami perbaikan setelah mendapatkan besi supplemental. Pasien juga mengalami masalah non medis seperti gangguan psikososial karena tertinggal pelajaran dibandingkan teman sebayanya, gangguan kualitas hidup, merasa rendah diri dan malu bergaul dengan teman sebaya, ketakutan pasien untuk beraktifitas karena merasa lemah, tidak kuat untuk berdiri lama dan nyeri pada luka bekas operasi. Keluarga juga memiliki permasalahan seperti biaya kontrol ke rumah sakit dan kekhawatiran ibu tidak sanggup mengatur pemberian makanan bernilai gizi tinggi untuk anak.

Pasien dilakukan pemantauan pertumbuhan dan perkembangan secara berkala dengan mengukur kenaikan berat badan dan tinggi badan, memantau perkembangan anak dengan Pediatric Symptom Checklist (PSC) 17 dan pemantauan kualitas hidup dengan pediatric quality of life (PedQL) dan kemungkinan komplikasi penyakit.

Keluarga pasien dianjurkan untuk meningkatkan pengetahuan tentang cara pengolahan dan pemberian makanan serta memantau tumbuh kembang pasien, meningkatkan pengetahuan mengenai penyakit gizi buruk sehingga berperan serta dalam pemulihan, meningkatkan pendapatan keluarga, meningkatkan higiene dan sanitasi lingkungan dengan pembuatan jamban keluarga.

Hasil Pediatric Symptom checklist (PSC) 17 didapatkan nilai internalisasi 4 dan perhatian 2 . Pediatric Quality of life (PedQL) didapatkan nilai 195,6. Awal pengamatan, anak mengalami gangguan fungsi fisik, emosi, sosial dan sekolah. Telah diberikan edukasi kepada keluarga untuk memberikan dorongan, mengembangkan potensi lain yang dimiliki seperti mengikuti kegiatan seni tradisional dilingkungan sekitarnya seperti kegiatan kelompok kesenian daerah, memberikan dukungan dan memperhatikan proses belajar anak, diet tinggi protein dan kalori dengan sumber protein yang tercapai oleh keuangan keluarga.

Pada pemeriksaan USG hepar dan saluran cerna tidak ditemukan tanda fatty liver dan cholestasis. Pada USG ginjal dan saluran kemih tidak ditemukan tanda urolithiasis. Pemeriksaan bone age dengan kesan average girl, perkiraan tinggi dewasa sekitar
$151,4 \mathrm{~cm}$, bone modelling baik dan rentang umur tulang antara 1 tahun 1 bulan sampai 15 tahun 1 bulan. Pemeriksaan bone survey tidak ditemukan tanda osteoporosis.

Prestasi sekolah anak membaik dengan nilai raport menduduki peringkat 4 dikelas dan juara 2 lomba mengaji di tingkat desa tersebut. Payudara telah berkembang dan anak mulai mendapatkan menstruasi dalam 2 bulan terakhir pemantauan dengan durasi 5-7 hari. Saat dilakukan penilaian ulang Pediatric Symptom checklist (PSC) 17 didapatkan nilai internalisasi 1, anak masih merasa cemas untuk melanjutkan pendidikan ke tahap Sekolah Menengah Pertama. PedQL didapatkan nilai 344,5 , perbaikan dari sebelumnya.

\section{PEMBAHASAN}

Pasien didiagnosis dengan gizi buruk tipe marasmik kwashiorkor kondisi III, perforasi yeyunum post laparatomi eksplorasi dengan Santulli prosedur dan yeyunostomi, short bowel syndrome dan anemia mikrositik hipokrom ec defisiensi besi. Pada anamnesis didapatkan keluhan nyeri perut berulang terutama bila mendapat makanan padat, muntah, diare persisten, penurunan nafsu makan dan berat badan. Pemeriksaan fisik didapatkan status gizi buruk dan lemak sub kutis tipis, crazy pavement dermatosis, baggy pant, distensi abdomen dengan pemeriksaan laboratorium ditemukan anemia dan tes darah samar pada feces.

Penelusuran etiologi selama rawatan didapatkan perforasi diikuti stenosis pada yeyunum dilokasi $50 \mathrm{~cm}$ dari ligamentum treizt sehingga dilakukan pemotongan yeyunum sepanjang $50 \mathrm{~cm}$, dilanjutkan dengan reanastomose dengan Santulli prosedur dan yeyunostomi. Setelah dilakukan yeyunostomi, cairan yang dikeluarkan dari stoma yeyunostomi sekitar $1.300 \mathrm{cc}$ sampai $1800 \mathrm{cc} /$ hari. Berat badan pasien mulai mengalami kenaikan dengan pemberian terapi kombinasi antara Formula 100 dengan pemberian parenteral nutrisi menggunakan IVFD D $17,5 \%$ ditambah protein berupa aminofuschin pediatric.

Gizi buruk terjadi akibat gangguan gizi kronik, ${ }^{2}$ disebabkan oleh multi faktor dan multi dimensi. ${ }^{5}$ Penilaian status gizi dilakukan dengan; (1) Anamnesis 
diet dan penyakit penyerta, (2) Pemeriksaan fisik, apakah sesuai dengan gejala klinis marasmus, kwashiorkor atau marasmik-kwasihorkor dan (3) Pengukuran antropometrik ditunjang pemeriksaan laboratorium. ${ }^{6}$

Tidak terdapat perbedaan dalam penanganan ketiga jenis gizi buruk. Tatalaksana sesuai dengan 10 langkah tatalaksana gizi buruk berupa mengatasi hipoglikemia, hipotermia, dehidrasi, memperbaiki gangguan keseimbangan elektrolit, mengobati infeksi, memperbaiki kekurangan zat gizi mikro, memberikan makanan untuk stabilisasi dan transisi, selanjutnya makanan untuk tumbuh kejar, memberikan stimulasi untuk tumbuh kembang dan mempersiapkan tindak lanjut dirumah. ${ }^{7}$ Pasien dengan gizi buruk harus dimonitor secara periodik untuk menghindari relapsnya kondisi gizi buruknya. ${ }^{8}$

Short bowel syndrome (SBS) merupakan kondisi gangguan malabsorpsi akibat reseksi usus halus ekstensif. Prognosis SBS tergantung panjang usus halus yang tersisa, tempat reseksi, adanya kolestasis, penyebab reseksi dan usia pasien saat dilakukan reseksi, sangat mempengaruhi kapasitas fungsional dari usus halus dan potensi adaptasinya. ${ }^{9}$ Short bowel syndrome harus memenuhi dua konsep penting yaitu pemendekan usus dan kebutuhan pada nutrisi parenteral. The Canadian Association of Pediatric Surgeons dalam Sigalet (2001) mendefinisikan SBS sebagai suatu keadaan yang memerlukan nutrisi parenteral $>42$ hari setelah reseksi usus atau panjang usus yang tersisa $<25 \%$. ${ }^{10}$

Ada 3 tipe reseksi yang menimbulkan SBS yaitu (1) Reseksi pada jejunoileal dan anastomosis jejunocolic, (2) Reseksi predominan yeyunum, > $10 \mathrm{~cm}$ ileum terminal dan kolon (jejunum-ileum) dan (3) Reseksi jejunoileal, colectomy dan stoma (jejunostomy). ${ }^{11}$ Etiologi SBS sangat multifaktorial dan dapat terjadi pada usia berapapun. Pada pasien ini etiologi SBS adalah perforasi dan stenosis yeyunum dengan reseksi yeyunum sejauh $50 \mathrm{~cm}(40 \mathrm{~cm}$ dari ligamentum treizt) dan dilanjutkan dengan Santulli prosedur sehingga cairan yang dikeluarkan lebih banyak.

Yeyunum memiliki panjang sekitar $200 \mathrm{~cm}$ $300 \mathrm{~cm}$ dan merupakan tempat penyerapan > 90\% nutrien pada $100 \mathrm{~cm}-150 \mathrm{~cm}$ awal usus halus. Hormon yang dikeluarkan yeyunum meliputi hormon kolesistokinin, sekretin, gastric inhibitory peptide dan vasoactive inhibitory peptide yang memegang peranan penting dalam proses absorpsi. ${ }^{12}$

Etiologi perforasi yeyunum pada pasien ini tidak diketahui. Beberapa etiologi perforasi yeyunum yaitu karena infeksi tuberculosis intestinal, ${ }^{13}$ perforasi karena lymphoma Burkitt, $^{14}$ perforasi ulkus di yeyunum. ${ }^{15}$ Kehilangan bagian yeyunum terutama 100 $\mathrm{cm}$ bagian awal yeyunum akan mengakibatkan kehilangan absorpsi nutrien lebih banyak dibandingkan kehilangan pada ileum pada panjang yang sama karena vili diyeyunum lebih panjang dengan kripti lebih dalam dan enzim dimikrovilli lebih aktif sehingga penyerapan nutrisi lebih besar. ${ }^{16}$

Pasien dengan yeyunostomi akan mengalami masalah dehidrasi setelah operasi terutama bila mendapatkan makanan oral. Sekresi cairan gastrointestinal terdiri dari 0,5 liter saliva, 2 liter cairan lambung dan 1,5 liter sekresi pankreasbilier yang tidak mampu diabsorpsi bila terjadi reseksi yeyunum pada $100 \mathrm{~cm}$ proksimal. Untuk menjaga status nutrisi tetap optimal selama periode adaptasi jangka panjang usus halus yang tersisa maka diberikan parenteral nutrisi sebagai tatalaksana utama. Asupan oral atau enteral tetap diberikan untuk menjaga patensi usus halus dan meningkatkan proses adaptasi fisiologis. ${ }^{11}$

Adapun tipe diet yang digunakan pada short bowel syndrome adalah: ${ }^{17}$

a. Formula enteral:

- Karbohidrat: biasanya tidak dapat ditoleransi baik karena keterbatasan mukosa area absorpsi dan menimbulkan peningkatan osmotik pada usus halus distal dan kolon sehingga sebaiknya diberikan tidak melebihi $40 \%$ dari kalori dan bebas laktosa.

- Lemak: terbaik adalah medium-chain triglycerides (MCTs), secara cepat terhidrolisa oleh enzim lipase pankreas dan tidak tergantung kepada luas permukaan untuk absorpsi adekuat dan secara cepat dibawa ke sirkulasi portal tetapi biasanya kadar asam lemak essensialnya tidak ada. Intake berlebihan dapat menyebabkan diare dan ketosis. Jumlah yang direkomendasikan tidak melebihi dari $60 \%$. 
- Protein: berupa protein yang terhidrolisa.

b. Parenteral nutrisi

Penggunaan parenteral nutrisi pada pasien ini bertujuan sebagai sumber utama nutrisi karena penyerapan nutrisi pasien dari saluran cerna terganggu dan mencegah deplesi nutrisi pada pasien yang tidak mampu mentoleransi nutrisi enteral. Parenteral nutrisi sebaiknya diberikan dengan menggunakan jalur sentral dan dilakukan evaluasi setiap 2-3 minggu berupa pemeriksaan klinis, berat badan, tinggi badan, laboratorium dan nilai intake. ${ }^{18}$

Komplikasi dari short bowel syndrome dan penggunaan nutrisi parenteral lama berupa sepsis yang berhubungan dengan katerisasi intravena dan trombosis, gangguan tulang seperti osteoporosis karena gangguan absorpsi vitamin D dan kalsium, esophagitis dan ulkus peptikum karena hilang atau berkurangnya mekanisme umpan balik negatif sekresi gastrin dan menimbulkan hipersekresi. Kerusakan hati juga merupakan komplikasi berikutnya yang terjadi karena adanya risiko kolestasis dan kolelithiasis karena gangguan aliran empedu. Gangguan siklus enterohepatal merubah komposisi kolesterol dan penurunan hormon intestinal akan menurunkan aliran empedu. ${ }^{16}$

Asidosis metabolik kronik dapat terjadi karena hilangnya bikarbonat pada feses dan gangguan ginjal karena terjadinya dehidrasi. Komplikasi lain dari short bowel syndrome adalah nefrolitihiasis yang kemungkinan disebabkan oleh deplesi cairan tubuh, asidosis metabolik, hipomagnesemia, penurunan perfusi ginjal dan jumlah urine dan eksresi sitrat. Untuk mencegahnya dengan meningkatkan hidrasi dan jumlah urine pada pasien. ${ }^{12}$ Pasien SBS yang telah dihentikan pemberian parenteral nutrisinya masih memiliki risiko gangguan malabsorpsi nutrien sehingga dibutuhkan pemantauan jangka panjang berkesinambungan dan pemberian nutrisi yang baik untuk mencegah defisiensi mikronutrien. ${ }^{19}$

Untuk mendapatkan tumbuh kembang optimal bukanlah hal yang mudah. Banyak faktor yang mempengaruhi tumbuh kembang anak yaitu status anatomik, fisiologik, kompetensi fisiologik dan lingkungan disekitar anak. Pada anak dengan gangguan kondisi kesehatan lama/kronik dapat terjadi gangguan dalam tumbuh kembangnya akibat kelainan pada satu atau lebih faktor diatas. Dampaknya anak dapat mengalami keterlambatan dalam perkembangan kognitif, komunikasi, motorik, adaptif atau sosialisasi dibandingkan dengan anak normal. Penyimpangan tumbuh kembang terjadi akibat dari gejala/kelainan yang menetap, pengobatan yang lama, keterbatasan aktifitas atau mobilitas atau keterbatasan kegiatan disekolah, rekreasi, bermain, aktifitas keluarga dan pekerjaan. $^{20}$

Pasien juga mengalami anemia defisiensi besi yang rentan terjadi pada anak dibawah usia 2 tahun, remaja khususnya remaja perempuan yang telah mengalami menstruasi, ibu hamil dan lanjut usia/geriatrik berusia 65 tahun keatas. ${ }^{12}$ Anemia pada pasien ini selain disebabkan karena periode pertumbuhan cepat juga karena intake rendah zat besi dan anak mulai mengalami menstruasi. Tatalaksana pada pasien diberikan terapi zat besi yang direkomendasikan diberikan hingga 2 bulan setelah $\mathrm{Hb}$ normal tercapai. Dosis terapi rekomendasi untuk anak perempuan adalah $15 \mathrm{mg} / \mathrm{kgBB} /$ hari. Anemia defisiensi besi dapat menimbulkan komplikasi seperti koilonikia, atrofi papil lidah, glossitis, stomatis dan mudah infeksi, gangguan prestasi belajar dan gangguan mental dan jangka panjang menyebabkan gangguan tumbuh kembang. ${ }^{21}$

Pasien menunjukkan perbaikan klinis dan gizi yang cepat setelah menjalani operasi ke dua karena telah ditutupnya stoma yeyunostomi dan perbaikan nafsu makan. Pada pengamatan terakhir, status gizi anak menjadi gizi baik dan tinggi badan berada dalam rentang potensi tinggi genetik serta psikososial mengalami perbaikan juga prestasi sekolah anak membaik. Kematian pada pemantauan jangka panjang anak dengan gizi buruk biasanya bila disertai penyakit penyerta lain seperti infeksi HIV dan anemia berat, usia < 12 bulan, beratnya derajat gizi buruk yang dialami dan adanya disabilitas.

Pemantauan jangka panjang dapat menurunkan angka morbiditas dan gangguan pertumbuhan dan perkembangan. ${ }^{22}$ Penelitian lain menemukan penyakit kardiovaskular dan metabolik pada pemantauan jangka panjang gizi buruk seperti peningkatan kolesterol dan $\mathrm{HbA} 1 \mathrm{C}$ (Haemoglobin 
glycated A1c) yang berisiko diabetes mellitus dan gangguan pubertas. ${ }^{23}$ Pasien ini tidak ditemukan tanda gangguan metabolik seperti obesitas dan proses pubertas anak normal.

\section{SIMPULAN}

Gizi buruk terjadi akibat gangguan gizi kronik yang disebabkan oleh multi faktor dan multi dimensi. Penatalaksanaan yang tepat pada penderita gizi buruk dengan short bowel syndrome et causa perforasi yeyunum memberikan hasil akhir yang baik. Pemantauan jangka panjang memberikan luaran yang optimal terhadap pertumbuhan dan perkembangan remaja dengan gizi buruk dimasa pacu tumbuhnya.

\section{UCAPAN TERIMAKASIH}

Terimakasih kepada semua pihak atas bimbingan, bantuan dan kontribusi dalam melaksanakan penulisan ini.

\section{DAFTAR PUSTAKA}

1. World Health Organization (WHO). Guideline updates on the management of severe acute malnutrition in infants and children. Geneva: WHO. 2013.

2. Departemen Kesehatan RI. Rencana aksi nasional pencegahan dan penanggulangan gizi buruk 20052009. Jakarta: Departemen Kesehatan RI; 2005.

3. Soetjiningsih, Suandi IKG. Gizi untuk tumbuh kembang anak. Dalam: Narendra Mb, Sularyo TS, Soetjiningsih, Suyitno H, Ranuh ING, Wiradisuria S, editor. Buku ajar I, Tumbuh kembang anak dan remaja. Edisi ke-1. Jakarta: Sagung Seto; 2002. hlm.22-50.

4. Devaera Y. Body image dan nutrisi remaja. Dalam: Kurniati N, Kaban RK, Chozie NA, Prawitasari T, Jasin MR, editor. Pendidikan kedokteran berkelanjutan LXXII. Transformation from fetus to excellent adolescents. Edisi ke-I. Jakarta: FKUI; 2017.hlm.25-9.

5. Schaible UE, Kaufmann SHE. Malnutrition and infection: complex mecanisms and global impacts. Plos Medicine. 2007;4(5):806-12.

6. Pudjiadi S. Ilmu gizi klinik pada anak. Edisi ke-4. Jakarta: Balai Penerbit FKUI; 2005.hlm.109-19.
7. Direktorat Jenderal Bina Kesehatan Masyarakat. Petunjuk teknis tatalaksana anak gizi buruk-buku I. Jakarta: Departemen Kesehatan RI, 2007.

8. Direktorat Jenderal Bina Kesehatan Masyarakat. Petunjuk teknis tatalaksana anak gizi buruk-buku II. Departemen Kesehatan RI, 2007.

9. Goulet O, Sauvat F. Short bowel syndrome and intestinal transplantation in children. Curr Opin Clin Nutr Metab Care. 2006;9:304-13.

10. Sigalet DL. Short bowel syndrome in infants and children: an overview. Semin Pediatr Surg. 2001;10:49-55.

11. Nightingale J, Woodward JM. Guidelines for management of patients with a short bowel. BMJ. 2006;55(suppl 4):iv1-iv12.

12. Parrish CR. The clinician's guide to short bowel syndrome. Nutrition Issues in Gastroenterology. 2005(3):67-99.

13. Ngonge AL, Ekaney DSM, Sama CB, MusongeEffoe J, Effoe VS, Ekwen G. Multiple jejunal perforation secondary to intestinal tuberculosis infection: a case report. Pan African Medical Journal. 2017;27:78.

14. Nayak SR, Rao GB, Yerraguntla SS, Bodepudi S. Jejunal perforation: a rare presentation of burkitt's lymphoma-succesful management. Oncol Med. 2014;10:1-4.

15. Ndoye NA, Konate I, Diouf C, Dieng M, Niang D, Ndour $\mathrm{O}$, et al. Peritonitis by jejunal ulcer perforation in child about one case. $\mathrm{J}$ Ped Surg Case Report. 2017;16:19-21.

16. Navarro F. Short gut syndrome. Dalam: Guandalini $\mathrm{S}$, editor. Essensial pediatric gastroenterology, hepatology, and nutrition. Edisi ke-1. Chicago: McGraw-Hill;2005.hlm.231-9.

17. Goulet O. Malabsorptive disorders and short bowel syndrome. Dalam: Koletzko B, Cooper P, Makrides M, Garza C, Uauy R, Wang W, editor. Pediatric nutrition in practice. Switzerland: Karger ;2008.hlm. 171-7.

18. Aqulina A, Bisson R, Brennan J, Carricato $M$, Connolly B, Green G, et al. Dalam: Kean P, editor. Guidelines for the administration of enteral and parenteral nutrition in paediatrics. Edisi ke-3. Canada. 2007.hlm.57-84.

19. Wu J, Tang Q, Feng $Y$, Huang J, Tao $Y$, Wang $Y$, 
et al. Nutrition assessment in children with short bowel syndrome weaned off parenteral nutrition: a long term follow-up study. J Ped Surg. 2007; 42:1372-6.

20. Soetjiningsih. Tumbuh kembang anak dengan kondisi kesehatan kronik. Dalam: Narendra MB, Sularyo TS, Soetjiningsih, Suyitno H, Ranuh ING, Wiradisuria S, editor. Buku ajar II. Tumbuh kembang anak dan remaja. Edisi ke-1. Jakarta. Sagung Seto; 2005.hlm.61-70.

21. Gatot D. Anemia defisiensi besi. Dalam: Widodo AD, Debora, Surya D, Waiman E, Tumbelaka I, Wigati $\mathrm{R}$, editor. Faktor lingkungan sebagai determinan tumbuh kembang anak. Edisi ke-3. Jakarta. 2014.hIm.17-26.

22. Kerac M, Bunn J, Chagaluka G, Bahwere $P$, Tomkins A, Collin S, Seal A. Follow up of post discharge growth and mortality after treatment for severe acute malnutrition (FuSAM Study): a prospective cohort study. PLoS one.2014;9(6):1-10

23. Lelijveld N, Seal A, Wells JC, Kirkby J, Opondo C, Chimwezi E, et al. Chronic disease outcomes after severe acute malnutrition in Malawian children (CroSAM): a cohort study. Lancet. 2016;s2214$109 \times(16) 30133-4: 1-9$. 